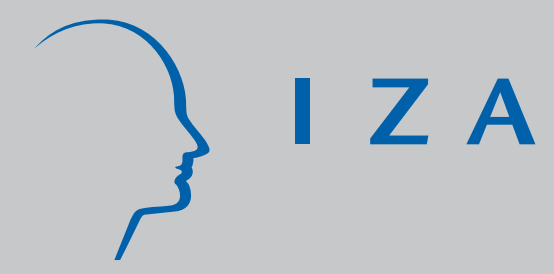

IZADP No. 2273

Part-Time Pensions and Part-Time Work in Sweden

Eskil Wadensjö

August 2006 


\title{
Part-Time Pensions and \\ Part-Time Work in Sweden
}

\author{
Eskil Wadensjö \\ SOFI, Stockholm University \\ and IZA Bonn
}

Discussion Paper No. 2273

August 2006

\author{
IZA \\ P.O. Box 7240 \\ 53072 Bonn \\ Germany \\ Phone: +49-228-3894-0 \\ Fax: +49-228-3894-180 \\ Email: iza@iza.org
}

\begin{abstract}
Any opinions expressed here are those of the author(s) and not those of the institute. Research disseminated by IZA may include views on policy, but the institute itself takes no institutional policy positions.

The Institute for the Study of Labor (IZA) in Bonn is a local and virtual international research center and a place of communication between science, politics and business. IZA is an independent nonprofit company supported by Deutsche Post World Net. The center is associated with the University of Bonn and offers a stimulating research environment through its research networks, research support, and visitors and doctoral programs. IZA engages in (i) original and internationally competitive research in all fields of labor economics, (ii) development of policy concepts, and (iii) dissemination of research
\end{abstract} results and concepts to the interested public.

IZA Discussion Papers often represent preliminary work and are circulated to encourage discussion. Citation of such a paper should account for its provisional character. A revised version may be available directly from the author. 


\section{ABSTRACT}

\section{Part-Time Pensions and Part-Time Work in Sweden}

Sweden had a special partial pension scheme between 1976 and 2001. It was one of three part-time pension schemes in the social security system. The other two were a partial early old-age pension, and a partial disability pension. The special partial pension scheme became very popular with a high take-up rate and was criticized for being too expensive. As a part of the decision on the old age pension scheme in 1994, the partial pension scheme was made less generous, and the scheme was totally abolished from year 2001. The other two options for combining work and receiving a pension continue. In this paper the effect on the total number of hours worked of the subsidized part-time pension system is analysed. The analysis indicates that the effect that people continue to work part-time instead of taking an early exit route is larger than the effect that people who would have continued to work fulltime until ordinary retirement age instead work part-time.

JEL Classification: H55, J22, J26, J14

Keywords: $\quad$ part-time work, part-time pension, older workers, labour supply

Corresponding author:

Eskil Wadensjö

Swedish Institute for Social Research

Stockholm University

SE 10691 Stockholm

Sweden

E-mail: Eskil.Wadensjo@sofi.su.se

\footnotetext{
* I am grateful for comments by Per Gunnar Edebalk, Gabriella Sjögren Lindquist, Ann-Charlotte Ståhlberg and Annika Sundén for comments on an earlier version and also for comments on the ESPE conference in Bergen June 2004 and the conference on Changing Social Policies for Low-Income Families and Less Skilled Workers in the EU and the US at National Poverty Center and European Union Center University of Michigan April 2005.
} 


\section{PART-TIME PENSIONS AND PART-TIME WORK IN SWEDEN}

\section{Why a policy for increasing the labour supply?}

The forecasts of the demand for labour in Sweden have varied with the business cycle during most of the post-war period. This can easily be seen by studying the five-year forecasts made by the Ministry of Finance. The analysis and the recommendations vary with the year of publication. In years of prosperity the conclusion has been that the labour supply is too small and that measures have to be taken to increase the supply. In recession years the lack of demand has been in focus and that measures should be implemented to decrease labour supply. Since the of the 1980s, irrespective of the business cycle, worry that the declining share of the population who are of active age ${ }^{1}$ and the resultant decline in labour supply would lead to problems in financing the welfare state has dominated the debate. Many measures were also implemented in the 1990s in an attempt to increase the labour supply, but in the same decade measures were also introduced which (intentionally or not) contributed to diminishing the labour supply. ${ }^{2}$ Although these measures have not solved the problem, they have served to make it more visible.

The reason for the changed focus of the debate is the increasing awareness that the share of older people in the population is increasing all the time and the increase is not compensated by the decline of the share being below active age. The share of the population who are of active age is declining. This is not a new phenomenon but people have become more aware of it in recent years, perhaps as a result of that other countries, not least other EU countries, are also experiencing the same development as Sweden and we are influenced by the debate in those countries. See Table 1 for the development in some countries.

\footnotetext{
${ }^{1}$ The term "active age" is usually defined as the age from completion of the compulsory school to the normal (ordinary) retirement age according to the social security pension system, which is presently from 16 to 65 in Sweden. This means that what we mean by active age may vary over time (by changes in the school system and the pension system) and differs between countries. Many people who are of active age are not employed and there are those who are either below or above active age who are employed.

${ }^{2}$ For a survey see Wadensjö \& Sjögren (2000).
} 
Table 1 . The share of the population in some countries who are 65 years old and over and 80 years old and over (\%)

\begin{tabular}{|c|c|c|c|c|c|c|c|c|}
\hline \multirow[t]{2}{*}{ Country } & \multicolumn{2}{|c|}{1975} & \multicolumn{2}{|c|}{2000} & \multicolumn{2}{|c|}{2015} & \multicolumn{2}{|c|}{2030} \\
\hline & $65+$ & $80+$ & $65+$ & $80+$ & $65+$ & $80+$ & $65+$ & $80+$ \\
\hline Denmark & 13.4 & 2.4 & 14.9 & 4.0 & 18.9 & 4.4 & 23.0 & 7.1 \\
\hline Norway & 13.7 & 2.5 & 15.2 & 4.4 & 17.4 & 4.6 & 22.0 & 6.6 \\
\hline Sweden & 15.1 & 2.7 & 17.3 & 5.0 & 21.4 & 5.7 & 25.1 & 8.6 \\
\hline France & 13.5 & 2.5 & 16.0 & 3.7 & 18.8 & 5.8 & 24.0 & 7.5 \\
\hline Germany & 14.8 & 2.2 & 16.2 & 3.5 & 20.2 & 5.4 & 25.8 & 7.2 \\
\hline Italy & 12.0 & 1.9 & 18.1 & 4.0 & 22.2 & 6.8 & 28.1 & 9.0 \\
\hline $\begin{array}{l}\text { United } \\
\text { Kingdom }\end{array}$ & 14.0 & 2.4 & 15.7 & 4.0 & 18.4 & 4.9 & 23.5 & 7.0 \\
\hline Japan & 7.9 & 1.1 & 17.0 & 3.7 & 24.9 & 7.0 & 28.3 & 11.1 \\
\hline $\begin{array}{l}\text { United } \\
\text { States }\end{array}$ & 10.5 & 2.1 & 12.6 & 3.3 & 14.7 & 3.8 & 20.0 & 5.3 \\
\hline
\end{tabular}

Source: U.S. Department of Commerce, Economics and Statistics Administration, and U.S. Census Bureau, An Aging World 2001, Washington, D.C., 2002.

There are two factors behind the development towards an aging population. The first factor is that fertility is low, below the level leading to a non-declining population. New cohorts are smaller than earlier cohorts and the population pyramid is not a pyramid anymore. The other factor is that people are living longer. In the early decades of the 20th century, life expectancy increased primarily because child mortality and mortality among those of active age declined. Mortality in epidemic diseases was drastically reduced. During the most recent decades life expectancy has mainly increased due to that those who reach retirement age live more years after reaching that age. This form of increase in life expectancy has a greater effect on the share of the population who are of old age than 
the earlier dominating forms of increase in life expectancy. The effect will be magnified when the baby boom cohorts from the 1940s reach retirement age. This is another reason for the present intense discussion on the effects of the aging of the population.

As seen in Table 1 the share who are 80 years old and over is increasing strongly. This means that not only the pension costs but also the costs for old age care and health services will increase considerably.

The main factors behind the aging of the population are the increase in life expectancy and low fertility. That we live longer is a very positive development. Fertility may be influenced to some extent by the family and education policy. But we should not expect any large effects and a rise in fertility will only have an effect on labour supply with a lag of about 20 years. In the first decades after an increase in the fertility rate the share of the population who are of active age will decline. The measures which may increase the number of hours worked in the economy do not influence the two main factors behind the increase of the old age share, but are targeted towards increased labour force participation among different demographic groups. This will be discussed in the next section of the paper.

\section{Policies aimed at increasing the number of working hours in the economy}

When the old age share of the population increases and the number of hours worked declines, the most obvious measures are those that counteract the decline in employment among older workers. It is not evident, however, that this is the most efficient method of increasing the number of hours worked. And even if it is, it is not the only possible way to go for increasing the number of hours worked. Following are some different methods for increasing labour supply and employment, including measures that are focused on increasing labour supply among older workers.

- On average, entry into the labour market occurs later now than some decades ago. This is partly due to that the period in school has been lengthened. The nine-year period in the compulsory primary school has been prolonged by three years in secondary school for almost everyone. A gradually increasing share of the cohort 
also continues on to higher education. But this is only part of the explanation. Entry into the labour market is delayed by more years on average than the lengthening of the period in education. It takes a longer time to go from completed secondary school or university to employment. And many people wait a few years after secondary school before continuing on to higher education. Measures that facilitate for young people finding work after education, and easier access to university education for those who have completed secondary school may be of value.

- Labour force participation is considerably lower among some groups of active age than among other groups. Recently arrived refugees especially, have very low labour force participation and a high unemployment rate. A better policy for integrating immigrants in the labour market and society in general may be a way to increase employment. One measure that has been proposed is to encourage labour force immigration. Labour migrants are young and have a high employment rate - they are actively recruited to jobs in most cases.

- The number of hours worked is not only influenced by the labour force participation rate and the employment rate but also by to what extent people who are employed are actually working. The most common reason for absence from the work place is illness. ${ }^{3}$ Measures to decrease sickness absence would, if they are efficient, be a way of counteracting the decline in the number of hours worked due to increase in the old age share of the population.

Most of the proposals however are focused on increasing labour supply and the number of hours worked among people of older active age (55-64) or above active age (65+). The goals regarding labour force participation among older people may be divided in three sub-goals.

- To decrease early exit from the labour force and in that way increase the number of hours worked in the economy. Early exit has tended to increase during the last

\footnotetext{
${ }^{3}$ See the different papers in Swedenborg (2003).
} 
decades in Sweden and even more so in many other countries. The exit follows many routes, in Sweden for example through disability pensioning ${ }^{4}$ and by pensions paid by the employer, but there are many other routes out of the labour market.

- To increase the formal retirement age. Such a change may relate either to the normal retirement age and/or to the minimum age for getting an early old age pension. ${ }^{5}$ During the last two decades many countries have raised the retirement age in at least one of these two respects. In several countries the previous lower retirement age for women has been raised to the same age as for men. Some countries with a retirement age lower than 65 have raised it to 65 . In the U.S. a decision was made to raise the retirement age gradually from 65 to 67 . This was decided already in 1983 and the first enhancement to 651/2 years took place in 2002 for those born in 1937. The first cohort who will retire at age 67 will be those who were born in 1955 for which the "normal” retirement year will be 2022.

- To facilitate work after the formal retirement age. In some countries many people continue to work after retirement age. In the U.S., mandatory retirement for those up 70 years of age was prohibited in 1978. In 1987 mandatory retirement was prohibited also for those 70 years and older with only a few exceptions. Income testing for those 65 years and older was discontinued from year 2000. Income testing remains for those who are between the ages from 62 and 65. In Sweden the law on employment security has been changed to hinder the earlier common mandatory retirement at age 65 . The new age limit has been set to 67 years. However, it will not be possible to get unemployment benefits after the age of 65 and sickness benefits only to a limited extent after the age of $65{ }^{6}$

\footnotetext{
${ }^{4}$ The disability pension system and also the names of the different forms of disability pensions were changed from January 2003.

${ }^{5}$ See Turner (2003) for a survey of recent increases of the lowest possible age for an old age pension which have been made in various countries.

${ }^{6}$ For those who have reached the age of 65 but not yet 70 and who have received sickness benefits for 180 days, the insurance society may decide that they should no longer be eligible for sickness benefits. Those who are 70 years and older and still work may only get sickness benefits for 180 days.
} 
How does a part-time pension system fit into that system of reforms? In a formal sense a part-time pension means that instead of continuing full-time work, a person changes to part-time work some years before full-time retirement, i.e. a reduction in the number of hours worked. Might such a working-time reduction lead to that more hours are worked in the economy in practice? We will now proceed to this question.

\section{Effects of a part-time pension system on labour supply, employment, and number of hours worked}

If everyone had continued to work until 65 years of age, the introduction of a part-time pension system would have reduced the labour supply if measured by the number of hours worked. However, it is more complicated than that. Many people leave the labour force before the normal retirement age. Some do so early but many do so when they are 60-65 years old, in the same age span it was possible to get a part-time pension (in 1994 the lower age limit was raised to 61 years). It is not unlikely that the part-time pension leads to that people continue to work more years than if they had not had that option. In that case we will get two effects going in the opposite directions.

The discussion on the partial effects of the part-time pension system has had both a medical and an economic basis. It is possible to combine the two types of analysis. The starting point for the medical analysis is that there is a change in the work capacity with age. Research in this field indicates that the maximum capacity in many cases is the same well above the age of 60 , but that the ability to work at maximum capacity for an extended period of the day or week may be lower for older people than for younger ones. If the work is organized in a way that it requires use of the maximum capacity during a large part of the workday it may lead to problems for older workers. A negative solution, at least from the view of increasing labour supply, is that older workers leave the labour force with a disability pension or with other forms of economic support. A more positive solution is to adjust work tasks, work speed and working hours according to age. One example is a change from full-time to part-time work. An indication that people could continue to work if the working conditions were adjusted is given by the results of Statistics Sweden's survey of work environment. See Table 2. The answers in the table 
indicate that a shorter work-week is only one of several possible ways of changing the working conditions. ${ }^{7}$

Table 2. Possibilities of being able to work until the ordinary retirement age among people aged 50-64 years

\begin{tabular}{|c|c|c|c|c|}
\hline & \multicolumn{2}{|c|}{ Men (\%) } & \multicolumn{2}{|c|}{ Women (\%) } \\
\hline $\begin{array}{l}\text { Currently have difficulties in fulfilling the work } \\
\text { tasks due to age }\end{array}$ & \multicolumn{2}{|c|}{7.7} & \multicolumn{2}{|c|}{8.4} \\
\hline $\begin{array}{l}\text { Believe that it will not be possible to work until } \\
\text { ordinary retirement age in the present occupation }\end{array}$ & \multicolumn{2}{|c|}{12.7} & \multicolumn{2}{|c|}{14.7} \\
\hline $\begin{array}{l}\text { Changes that have to be made to make it possible to } \\
\text { continue in the present occupation until ordinary } \\
\text { retirement age among those who do not believe it } \\
\text { will possible to work until ordinary retirement age }\end{array}$ & $\begin{array}{l}\text { Blue- } \\
\text { collar }\end{array}$ & $\begin{array}{l}\text { White- } \\
\text { collar }\end{array}$ & $\begin{array}{l}\text { Blue- } \\
\text { collar }\end{array}$ & $\begin{array}{l}\text { White- } \\
\text { collar }\end{array}$ \\
\hline Shorter working hours & 53.3 & 49.8 & 48.9 & 66.9 \\
\hline Change in the lay-out of the working hours & 18.6 & 21.5 & 21.4 & 24.0 \\
\hline Changes in the physical working requirements & 45.6 & 15.5 & 49.6 & 22.3 \\
\hline Changes in psycho-social working environment & 25.3 & 36.8 & 35.7 & 54.9 \\
\hline Changes in the work intensity & 50.2 & 51.6 & 51.1 & 65.2 \\
\hline
\end{tabular}

Source: Statistics Sweden (2004), The Work Environment 2003.

There are arguments in favour of adjusting the working conditions for older workers, but why are these adjustments not taking place? Employees and employers could agree on reduced working hours for example. One explanation may be that there are economic arguments on the local level favouring other types of solutions.

A reduction in working hours which is combined with a part-time old age pension from the social security pension scheme means a reduction in the pension paid out both before and after the take up of the pension. More important is probably that the collectively bargained occupational pensions boost the effects to a high extent. The explanation is that

\footnotetext{
${ }^{7}$ A comparison of the work environment studies of 2001 and 2003 shows that the share who believe that it will not be possible to work until ordinary retirement age in the present occupation declined to a great extent between 2001 and 2003.
} 
the compensation in the social security pension scheme for income parts over the ceiling is based on the earnings in the years immediately before retirement. ${ }^{8}$ For example, a change to half-time work means that the basis for that pension is drastically reduced and the pension will be much lower. ${ }^{9}$ A disability pension is economically a much better alternative. The take-up of a disability pension means that the old age pension from the social security and occupational pension systems will not be reduced, and also in most cases to a higher compensation before 65. Other forms of early exit from the labour market that build on different forms of compensation may also be economically attractive. An alternative would be if the employer could offer half-time pensions instead of fulltime pensions when reducing personnel and maybe also in other instances. There may be some complications for the employer. More people have to leave to get the same reduction in hours worked and it could lead to problems with organizing work. To make solutions attractive the collectively bargained occupation pension schemes have to be adjusted.

A problem is that unsubsidized part-time work is an economically unattractive alternative for many people compared to full-time exit with compensation from social and occupational insurance schemes. Subsidized part-time pension, which was introduced in 1976, was economically very attractive. For many a part-time pension from the special part-time system was combined with compensation from complementing occupational insurances, giving replacement for income parts over the ceiling in the social insurance part-time pension scheme. The occupational old age pension schemes were also adjusted to compensate for the reduction in occupational pensions due to the working-time reduction. Before continuing with a discussion on how to study the effects of the parttime system we will say something about the kind of effects we may expect.

- The first effect is the effect we started with. Some people who would have continued to work up to the ordinary retirement age will accept the offer of a parttime pension. The income loss for the individual is compensated by more leisure

\footnotetext{
${ }^{8}$ The pension for earnings over the ceiling in the social insurance system depends in the occupational pension system for those in the state sector on the earnings in the five years before the retirement age, for those employed in the counties and municipalities on the best five of the last seven years before retirement, and for white-collar workers in the private sector on the earnings in the year before retirement.

${ }^{9}$ For another example for that pension schemes may hinder part-time work see Even \& Macpherson (2004).
} 
time. The importance of the replacement rate may be seen by the large changes in new pensions following changes in the replacement rate.

- The other effect is also mentioned earlier in the paper: If the opportunity arises to get a part-time pension, some people will take that pension instead of leaving the labour market with a disability pension or another form of early exit compensation. The alternative part-time pension and early exit with compensation in one or another form may not be exactly coordinated in time. For example, a person may abstain from applying for a disability pension at age 60, if he knows that he may be able to get a part-time pension at age 61 (may be encouraged to continue to work full-time when the part-time pension option is close in time). A person may also abstain from applying for a disability pension at the age of 62 if he has been part-time pensioned at the age of 61 (the part-time pension may make it attractive to continue to work).

- A third effect of the part-time pension system is that it can influence labour force participation both directly and indirectly (through the labour supply decision). Part-time work may lead to a better health condition for example (compared to full-time work and maybe also compared to full-time leisure). Absence due to sickness (with sickness benefits) may therefore be lower and perhaps also the number of people who later apply for a disability pension. It may lead to a positive effect for the number of hours worked in the economy.

The conclusion of this discussion is that the total effect of the introduction of a part-time pension on labour supply is uncertain. There are different effects that work in different directions. Empirical studies are necessary to say if the total effect is positive or negative. They are not easy to carry out as the labour supply and changes in labour supply are influenced by many other things than the introduction of a part-time pension system. We shall try to answer the question in several different ways. First we will discuss in general terms how part-time work and labour force participation are related to each other. After that we will discuss some experiences from countries other than Sweden. In the next step 
we try to estimate the effects by making use of existing studies and data from the National Insurance Board.

\section{Part-time work and labour force participation}

The critical question is if a part-time pension system leads to a higher or lower number of hours worked in the economy. To answer that, certain questions have to be posed. The first question is if the part-time pension system leads to that more people are employed. The second question is how the number of hours worked per person is influenced. The combined answer to those two questions tells us how the total number of hours in the economy is influenced by the introduction of the scheme.

Part-time work is common in our economies not only among older people. We can learn something from the experiences of part-time work among other demographic groups. I will give some examples on experiences from part-time work below.

Women often work part-time in many countries, more so than men in the same age groups. Is part-time work among women combined with high labour force participation or low? This question has been dealt with by Jelle Visser (2002), who studies the pattern in the EU countries, and especially the development in the Netherlands. ${ }^{10}$ He finds a strong positive correlation between the share of women who work part-time and the number of women who are employed. In countries like Greece, Italy and Spain few women are employed and a low share of them are working part-time, and in countries like Denmark, Sweden and the United Kingdom many women are working part-time and the female employment rate is high. In the Netherlands a rapid expansion of part-time work has been accompanied by a rapid rise in the female employment rate. One interpretation of the development is that in countries in which women have previously had a low employment rate, women now enter the labour market by part-time work, and that the possibilities of getting part-time work facilitate that process. Sweden had such a development in the 1970s and the 1980s, when the female employment rate rose at the same time as the part-time rate among employed women increased. During the last two

\footnotetext{
${ }^{10}$ See also Rasmussen et al. (2004) for the development of part-time work among different groups in New Zealand, the Netherlands and Denmark.
} 
decades more women have started to work full-time (or long part-time) in Sweden, and the female employment rate has continued to be high. According to Visser it is not selfevident that the development will go the same way in the Netherlands as in Sweden. The Netherlands may continue to be a part-time country on a permanent basis.

Young people are another group who often work part-time. In many cases part-time work is combined with (full-time) studies in high school or university. As mentioned earlier the transition from education to permanent jobs is taking place at a gradually higher age. However, there are large differences in labour force participation between different countries. Countries that have early entry into the labour force are mainly those who have an apprenticeship system (not only during the years the apprenticeship lasts) and those where it is common to work alongside studying. Both cases indicate that an early introduction of part-time work with part-time (or full-time) studies may be a way of increasing labour supply. ${ }^{11}$

A third group of part-time workers are those who combine part-time work with a parttime disability pension. In Sweden it is rather common to combine work and a disability pension (granted on medical indications) and the share of the disability pensions which are part-time pensions has increased. An important question is how the existence of this option influences the labour supply. Cross-country comparisons indicate that labour force participation is relatively high among disabled people in Sweden.

The experiences accounted for here do not show that a high rate of part-time work necessarily implies that the rate of full-time work is reduced to the same extent. The total share of employed people may be higher. If this means that the total number of working hours is higher in countries with a high incidence of part-time is another question. There are good arguments for doing a study of the same type as Visser's (2002), and this time compare the share of part-time employment and the employment rate among people of older active age. Is it so that countries that have a high part-time employment rate among older people also have a high employment rate in the same age group?

We have done such a study based on observations for the EU countries for the period 1990-2003. The results are given in Tables 3 and 4 below. In both tables the part-time

\footnotetext{
${ }^{11}$ See for example Ryan et al. (1991).
} 
share is the independent variable and the employment rate the dependent variable. Table 3 shows OLS estimates with controls for country and year of observation. In Table 4 fixed effect models are estimated (fixed effects for countries). The main results are that the sign of the coefficient for the part-time share is positive, as expected, in all estimations and that the estimates are significantly different from zero. The value of the coefficient for the part-time share is higher for those aged 55-59, especially for men, than for those aged 60-64.

Table 3. The employment rate in per cent of people aged 55-64 in the EU countries 19902003. OLS regressions with employment rate as the dependent variable and part-time share as independent variable.

\begin{tabular}{llllll}
\hline Group & Part-time share & Constant & Controls & $\mathrm{R}^{2}$ (adj) & $\begin{array}{l}\text { Number of } \\
\text { observations }\end{array}$ \\
\hline Men 55-59 & $.651(.166)^{* * *}$ & $62.14(1.37)^{* * *}$ & country, year & .902 & 191 \\
Men 60-64 & $.188(.050)^{* * *}$ & $15.31(1.37)^{* * *}$ & country, year & .980 & 191 \\
Women 55-59 & $.138(.047)^{* * *}$ & $16.18(1.92)^{* * *}$ & country, year & .975 & 191 \\
Women 60-64 & $.090(.025)^{* * *}$ & $3.91(1.33)^{* * *}$ & country, year & .963 & 191 \\
\hline
\end{tabular}

Notes: $* * *$ = significant on the $1 \%$ level; reference categories are Austria (country) and 1990 (year); observations are missing for Austria, Finland and Sweden for 1990-1994, and for Austria, Germany and Luxembourg, for 2003.

Data source: Eurostat.

Table 4. The employment rate in per cent of people aged 55-64 in the EU countries 19902003. Fixed effect regressions (for country) with employment rate as the dependent variable and part-time share as independent variable.

\begin{tabular}{lllll}
\hline Group & Part-time share & Constant & F $(1,175)$ & $\begin{array}{l}\text { Number of } \\
\text { observations }\end{array}$ \\
\hline Men 55-59 & $.543(.146)^{* * *}$ & $61.15(.91)^{* * *}$ & $13.78^{* * *}$ & 191 \\
Men 60-64 & $.118(.056)^{* *}$ & $32.41(.79)^{* * *}$ & $4.50^{* *}$ & 191 \\
Women 55-59 & $.345(.073)^{* * *}$ & $25.63(2.51)^{* * *}$ & $21.77^{* * *}$ & 191 \\
Women 60-64 & $.138(.025)^{* * *}$ & $11.22(1.02)^{* * *}$ & $29.54^{* * *}$ & 191 \\
\hline
\end{tabular}

Notes: $* * *=$ significant on the $1 \%$ level; $* *=$ significant on the 5 per cent level; observations are missing for Austria, Finland and Sweden for 1990-1994, and for Austria, Germany and Luxembourg, for 2003.

Data source: Eurostat. 


\section{International experiences of part-time pensions ${ }^{12}$}

Although there is a great interest in part-time pensions in many countries, there has not been much research on it. Most studies are based on macro indicators and not on individually based panel studies, which in most cases would be the preferred form. One possibility of finding out the effects could be to study countries with a high labour force participation (and employment) among older workers and try to relate to the institutional structure of those countries. In this section the experiences of two countries with high employment rates among older workers will be presented.

The first example is Japan, where 65 has been the normal (formal) retirement age for a long time in the social security pension system but with a possibility to take up an early old age pension from the age of 60 (but the pension has been income-tested between 60 and 65). Most people continue to work up to 65 and many even after that age. It is not explained that people continue to be employed according to "life-long" employment contracts. On the contrary it is the rule that people leave these career positions already before they reach the age of 60 , for example at the age of 58 . This type of retirement is called teinen. When leaving the career position the person receives a severance pay which could be converted to an annuity. Many use their severance pay to pay off their mortgage on the house, others to start their own business and continue to work in that capacity. But most people continue to work as employees. The employer has an important role in assisting the person who is leaving the career position to get a new job: in many cases in companies related to the earlier company (in most cases smaller companies), in other cases continued employment in the same company but not in the career position. The working hours are generally fewer in the new position and the work requirements less. Many continue in those types of jobs also after 65 and a not insignificant number even after 70. It is a type of gradual retirement but not in the form of a part-time pension scheme.

\footnotetext{
${ }^{12}$ See the various contributions in Delsen \& Reday-Mulvey (1998), and Latulippe \& Turner (2000) for surveys of the international experiences.
} 
In the U.S. mandatory retirement is prohibited by law. This could lead us to believe that many people continue to work at the same work-place up to the normal retirement age in the social security system (which is gradually enhanced from 65 to 67). But this is not the case. On the contrary, many leave their employment earlier, in many cases before the age from which it is possible to get a reduced old age pension from the social security pension system, i.e. from 62. What is the explanation for this? One important part of the explanation is that companies are designing company pension plans, where the value of the amount paid out is largest if people retire at a lower age than 65, for example at the age of 58. ${ }^{13}$ An early pension of that type would lead to a reduced economic standard if the pension is not complemented with other income. The pension is lower than the wage and the annual pension is lower if it is taken out early, even it is not reduced in an actuarially fair way. Many people combine that type of pension with earnings from a new job. That job is in many cases a part-time job and often a less demanding job than the earlier career one. Those jobs are called bridge or bridging jobs. Just like in the Japanese case it is a form of gradual reduction of the work load - a reduction which may explain that it is possible to continue to work until the ordinary retirement age and in some cases even longer. Also in the U.S. the new job may be in the same company, but due to the tax rules it is constructed as a termination of the job contract and a new work contract after a number of months (on part-time or on full-time in another position than the former one). This form of continued employment is often called "retire and rehire". ${ }^{14}$

A study has been made of the effects of the introduction of a part-time pension scheme at one of the campuses of University of North Carolina (see Allen 2004, and Allen et al. 2004). The results indicate that the share who retires increased after the introduction of the system. The increase in the share who retires is however less than the share who accepted a part-time pension. This means that of those taking up a part-time pension some would have continued to work full-time and some would have been full-time pensioners. The study also tries to answer the question of what characterizes those who

\footnotetext{
${ }^{13}$ Here should be underlined that only about half of the employed are covered by this type of pension and that only company plans and not the social security pensions have this form of non-actuarial construction. ${ }^{14}$ See Penner et al. (2000) for a detailed presentation of the tax-related explanation for this type of solution. See also Chen \& Scott (2002) for information on the design of this form of re-hiring.
} 
became part-time pensioners. It shows that the part-time pensioners are more similar to those who continue to work full-time than those who become full-time pensioners.

In Sweden people aged 60 to 65 continue to work to a high extent in an international perspective. Also Sweden has had a system for a gradual reduction of the work load - the part-time pension system - and there are still part-time solutions in the old age and the disability pension systems.

There are exceptions to the rule that countries in which many continue to work up to and over the ordinary retirement age have institutional solutions facilitating a gradual reduction in the work requirements and working hours with age. Iceland is the most obvious exception. ${ }^{15}$ In Iceland labour force participation is high and the work-week long among both men and women. And the Icelanders continue to work not only to 65 but also after that age, in many cases up to the age of 70 .

\section{Obstacles to part-time work and other forms of gradual working-time reduction before retirement}

Why has Sweden not tried more of the Japanese or the American type solutions, where people gradually reduce their work-load with advancing age by changing work tasks and in most cases also employers, and where the wages become lower but their income loss is partly or totally replaced by a pension paid by the employer?

A first explanation is that it takes time to develop such institutions, and it is difficult to go step-wise from one institutional set-up to another. The history is important - we have path dependency. ${ }^{16}$ The teinen system and the system with bridge jobs both build on that there is a functioning labour market for older people. With the Swedish institutional setup it would probably be better to start with phased retirement, i.e. to reduce the working time at the same work place.

Another explanation for that such systems have not been developed in Sweden is that the salary during the last years before retirement determines the size of the pension in the

\footnotetext{
${ }^{15}$ See Herbertsson (2001) for a presentation of the Icelandic case.

${ }^{16}$ See Pierson (2000) for a general discussion and Weaver (2003) for an application on pension policy.
} 
occupational pension system for those who have a pension over the ceiling in the social security system. The exception is the system for blue-collar workers in the private sector. A gradual, phased, retirement leads to a much lower pension. It means that for many people full-time work or full-time retirement are the two economically most favourable alternatives. A study of the occupational pension systems and their effects is highly motivated. Another factor that may reduce the changes of employers among older people is the law on employment security (LAS). A change of work-place leads to low seniority and therefore less job security.

A third explanation is that the costs for the employer may be higher if they employ older workers. It means that older workers who lose their job or who want to change have greater difficulties in getting a new job than younger workers. One example is that the average sick leave rate is higher for older people than for younger ones and the employers are obliged to pay compensation during the first three weeks a person is sicklisted.

\section{The Swedish part-time pension system}

As mentioned earlier there are only a few studies of the Swedish part-time system other than those that are based on aggregated data. ${ }^{17}$ One exception is Sundén (1994) whose study is based on the Level of Living Investigations (LNU) from 1974 and 1981. In the next section I will use results from Sundén's study together with calculations based on data from the National Social Insurance Board to estimate the effects of the part-time pension system. In this section information on the part-time pension system and part-time work in Sweden will be presented.

The part-time pension system was introduced in 1976. The part-time pension system was complemented with additional occupational part-time pensions for the main part of the employees (the main exception was blue-collar workers in the private sector). The parttime pension system became very popular in a short time. Many applied for and received a part-time pension. The most important steps in the development of the part-time

\footnotetext{
${ }^{17}$ See Ginsburgh (1985), Wadensjö (1993 and 1996) and Wise (1990).
} 
pension system are presented in Table 5. The replacement rate changed on three occasions. It was first lowered and later restored to its original level. In 1994 it was lowered again at the same time as other changes were made, changes which were the first steps towards the abolishment of the system. This was a part of the agreement on the new system for old age pensions. In accordance with that agreement, no new part-time pensions have been granted since year 2000 .

Table 5. The development of the Swedish part-time pension scheme

\begin{tabular}{|c|c|}
\hline Date & Event \\
\hline \multirow[t]{7}{*}{ July 1, 1976} & The part-time pension system started \\
\hline & - possible to get a part-time pension from 60 years of age \\
\hline & - the replacement rate was $65 \%$ of the loss in earnings \\
\hline & - the minimum reduction was 5 hours \\
\hline & - remaining working time had to be at least 17 hours and not more \\
\hline & than 35 hours \\
\hline & - financed by a special payroll fee \\
\hline \multirow[t]{2}{*}{ January 1, 1980} & Possible for self-employed to get a part-time pension; working \\
\hline & hours had to be reduced by at least half \\
\hline January 1, 1981 & The replacement rate decreased to 50 per cent \\
\hline July 1,1987 & The replacement rate increased to 65 per cent \\
\hline \multirow[t]{6}{*}{ July 1, 1994} & Several types of restrictions \\
\hline & - the minimum age increased to 61 years \\
\hline & - the replacement rate decreased to 55 per cent \\
\hline & - the maximum reduction of working hours was set to 10 hours (the \\
\hline & requirement that the self-employed with a part-time pension could \\
\hline & not work more than half-time was abolished) \\
\hline January 1, 1999 & The special payroll fee was discontinued \\
\hline December 31, 2000 & Last day for the start of a new part-time pension \\
\hline
\end{tabular}


Table 6. New and all part-time pensions 1990-2000

\begin{tabular}{|c|c|c|c|c|c|c|}
\hline Year & $\begin{array}{c}\text { New } \\
\text { part-time } \\
\text { pensions } \\
\text { men* }\end{array}$ & $\begin{array}{l}\text { New part- } \\
\text { time } \\
\text { pensions } \\
\text { women* }\end{array}$ & $\begin{array}{l}\text { Total number } \\
\text { part-time } \\
\text { pensions } \\
\text { men (in } \\
\text { December) } \\
\end{array}$ & $\begin{array}{l}\text { Total number } \\
\text { part-time } \\
\text { pensions } \\
\text { women (in } \\
\text { December) } \\
\end{array}$ & $\begin{array}{l}\text { Total number } \\
\text { part-time } \\
\text { pensions (in } \\
\text { December) }\end{array}$ & $\begin{array}{l}\text { Part-time pensions } \\
\text { per } 100 \text { persons } \\
\text { aged } 60-64 \text { with } \\
\text { sickness benefits } \\
\text { entitling earnings }\end{array}$ \\
\hline 1976 & \multicolumn{2}{|c|}{14792} & 10124 & 4436 & 14560 & 7 \\
\hline 1977 & \multicolumn{2}{|c|}{20337} & 22131 & 9378 & 31509 & 12 \\
\hline 1978 & \multicolumn{2}{|c|}{18494} & 29149 & 12764 & 41913 & 16 \\
\hline 1979 & \multicolumn{2}{|c|}{18243} & 33415 & 15239 & 48654 & 22 \\
\hline 1980 & \multicolumn{2}{|c|}{32882} & 46504 & 21333 & 67837 & 27 \\
\hline 1981 & \multicolumn{2}{|c|}{12521} & 43331 & 21310 & 64641 & 24 \\
\hline 1982 & \multicolumn{2}{|c|}{14641} & 40415 & 21317 & 61732 & 22 \\
\hline 1983 & \multicolumn{2}{|c|}{10497} & 34458 & 20179 & 54637 & 20 \\
\hline 1984 & \multicolumn{2}{|c|}{9794} & 28488 & 18716 & 47204 & 17 \\
\hline 1985 & \multicolumn{2}{|c|}{9233} & 21912 & 15726 & 37638 & 13 \\
\hline 1986 & \multicolumn{2}{|c|}{8184} & 18560 & 13620 & 32180 & 12 \\
\hline 1987 & \multicolumn{2}{|c|}{14712} & 21404 & 14332 & 35736 & 13 \\
\hline 1988 & \multicolumn{2}{|c|}{13964} & 23471 & 15001 & 38472 & 15 \\
\hline 1989 & \multicolumn{2}{|c|}{12383} & 23856 & 15355 & 39211 & 15 \\
\hline 1990 & 7077 & 4228 & 23200 & 14868 & 38068 & 15 \\
\hline 1991 & 7469 & 4623 & 22390 & 14462 & 36852 & 15 \\
\hline 1992 & 15374 & 10082 & 29268 & 18683 & 47951 & 19 \\
\hline 1993 & 9575 & 6484 & 29907 & 18701 & 48608 & 19 \\
\hline 1994 & 9261 & 6584 & 30959 & 19614 & 50573 & 22 \\
\hline 1995 & 499 & 373 & 23525 & 14608 & 38133 & 17 \\
\hline 1996 & 449 & 377 & 15874 & 9518 & 25932 & 11 \\
\hline 1997 & \multicolumn{2}{|c|}{821} & 8768 & 4834 & 13602 & 6 \\
\hline 1998 & \multicolumn{2}{|c|}{1258} & 3685 & 1995 & 5680 & 3 \\
\hline 1999 & \multicolumn{6}{|c|}{ No information for 1999} \\
\hline 2000 & & & & & 7699** & 3 \\
\hline
\end{tabular}

* Information on the number of men and women with part-time pensions is unavailable for 1976-1989 and 1997-1998; ** July.

Sources: Riksförsäkringsverket, Delpensioneringen t o m 1996, Statistikinformation Is-I 1997:2, and information from The National Insurance Board.

Table 6 shows the development over time of the number of people with compensation from the special part-time pension system. The variations are large, especially in the number of new pensions. The large increase in 1980 is explained by the decision to lower the replacement rate for newly granted pensions from 1981, a decision which was made 
already in 1980. Many who would have applied for a pension later hurried to apply already in 1980 to be able to get a pension with the old, higher replacement rate.

The increase in 1987 is explained by the increase in the replacement rate back to the original 65 per cent level. The large increase in new pensions in 1992 is explained by the Government's proposition of an abolishment of the part-time pension system (no new part-time pensions would be granted for those who had applied after a certain date. Many hurried to apply for a part-time pension. The Parliament, however, did not accept the proposal from the Government. After the drastic changes in the rules in 1994 the number of new part-time pensions declined dramatically and the number of part-time pensioners gradually fell to a very low level. The part-time pension system more or less disappeared before it was formally abolished.

A part-time pension combined with part-time work does not entail a fixed number of working hours. The minimum was set to 17 hours and the maximum to 35. Table 7 shows the number of working hours for those who had a part-time pension on December 31, 1993. The information is from the period before the maximum reduction in working hours was changed to ten hours for those with a new part-time pension. 
Table 7. The number of people according to (weekly) working hours after getting a parttime pension among those who had a part-time pension December 31, 1993

\begin{tabular}{lll}
\hline Numbers of hours worked & Men & Women \\
\hline 17 & 586 & 698 \\
18 & 424 & 483 \\
19 & 873 & 889 \\
20 & 10645 & 5467 \\
21 & 330 & 251 \\
22 & 222 & 284 \\
23 & 511 & 531 \\
24 & 3749 & 1678 \\
25 & 387 & 459 \\
26 & 193 & 245 \\
27 & 204 & 202 \\
28 & 345 & 523 \\
29 & 141 & 323 \\
30 & 1048 & 1347 \\
31 & 462 & 647 \\
32 & 5693 & 3301 \\
33 & 299 & 182 \\
34 & 323 & 260 \\
35 & 266 & 233 \\
\hline Total & 26701 & 18003 \\
\hline Sour Can
\end{tabular}

Source: Calculations made at the National Insurance Board. ${ }^{18}$

We see that some specific numbers of working hours are common among those with a part-time pension - 20 hours (half-time), 24 hours (three days full-time), 30 hours (3/4time) and 32 hours (four days full-time). A change from full-time (40 hours) to half-time (20 hours) is the most common working-time reduction, but the average reduction in working hours is less than 20 hours. Most people reduced their working-time from 40 hours (21914 of the men and 11084 of the women). Most of the others reduced their working hours from a level less than 40 hours, but surprisingly many reduced their working hours from a level higher than 40 hours, in some cases considerably more than 40 hours. This may have contributed to the popularity of the part-time system.

In Table 8 the numbers with different forms of part-time pensions in the social security system are shown for 1980 (before the reduction of the replacement rate), 1986 (after the reduction of the replacement rate), 1993 (after the increase of the replacement rate but

\footnotetext{
${ }^{18}$ The calculations were made in connection with the study which was published as Wadensjö (1996).
} 
before the last decrease of the replacement rate), and 2003 (the latest year for which statistical information is available for both disability pensions and early old age pensions). The table shows that the special part-time pension scheme dominates in 1980, 1986 and 1993. It is easy to see that changes in the replacement rate are important. The number of people with part-time pensions was much lower in 1986 than in 1980 and 1993. It is also possible to see that part-time disability pensions gradually became more frequent. There are variations in the number who have early (actuarially reduced) old age pensions which counteract the variations in the number who have the special part-time pension. However, the take-up rate is rather low in that scheme.

In 2003 the number of people with partial pensions in the early old age and disability pension systems is higher than in 1993. The increases in those two systems compensate only for part of the discontinuance of the special part-time pension scheme. There may be a new development of part-time pensioning under way, however. The number of partial early old age pensions increased from 3312 in 2003 to 7167 in 2004, i.e. with 116 per cent. It is especially the number of $1 / 4$-pensions which increases. This probably in most cases means that people reduce their work-week from 40 to 30 hours. 
Table 8. People aged 60(61)-64 years in different partial pension systems in 1980, 1986, 1993 and 2003

\begin{tabular}{|c|c|c|c|c|c|c|c|c|c|}
\hline & \multicolumn{2}{|c|}{1980} & \multicolumn{2}{|c|}{1986} & \multicolumn{2}{|c|}{1993} & \multicolumn{2}{|c|}{2003} \\
\hline & & Men & Women & Men & Women & Men & Women & Men & Women \\
\hline \multicolumn{10}{|l|}{$\begin{array}{l}\text { Disability } \\
\text { pension }\end{array}$} \\
\hline & $3 / 4$ & & & & & 183 & 99 & 1771 & 1678 \\
\hline & $2 / 3$ & 1400 & 2512 & 1110 & 2246 & 873 & 953 & 156 & 194 \\
\hline & $1 / 2$ & 4219 & 2854 & 7214 & 6030 & 8591 & 8584 & 9460 & 13594 \\
\hline & $1 / 4$ & & & & & 74 & 144 & 1481 & 4156 \\
\hline \multicolumn{10}{|c|}{$\begin{array}{l}\text { Early old } \\
\text { age pension }\end{array}$} \\
\hline & $3 / 4$ & & & & & 7 & 2 & 291 & 135 \\
\hline & $1 / 2$ & 416 & 79 & 2927 & 310 & 1985 & 437 & 1184 & 671 \\
\hline & $1 / 4$ & & & & & 150 & 35 & 654 & 377 \\
\hline $\begin{array}{l}\text { Part-time } \\
\text { pension }\end{array}$ & & 46504 & 21333 & 18506 & 13620 & 29907 & 18701 & $1300 *$ & $700 *$ \\
\hline & tal & 52123 & 23929 & 29811 & 22206 & 41770 & 28955 & 15643 & 21505 \\
\hline
\end{tabular}

* Estimated values.

Sources: Riksförsäkringsverket 1981 and 1985/86; Riksförsäkringsverket, Statistisk information 1994:2 and 1994:14; Information from the National Insurance Board.

Next we will turn to the development of part-time work among people of older active age in Sweden in the 1990s. Table 9 shows that the share who worked part-time among men aged 60-64 drastically declined after 1994, which can be attributed to the changes in the part-time system. There is no corresponding development among those aged 55-59, a group that was not encompassed by the part-time pension system and therefore not affected by the changes in that system. The discrepancy in the development between the two age groups shows that changes in the part-time pension system have been important for the development of part-time work.

Table 9. Per cent of men aged 55-64 with part-time work in 1990-2004

\begin{tabular}{llllllllllllllll}
\hline Age & 1990 & 1991 & 1992 & 1993 & 1994 & 1995 & 1996 & 1997 & 1998 & 1999 & 2000 & 2001 & 2002 & 2003 & 2004 \\
\hline $55-59$ & 6.4 & 6.0 & 7.4 & 6.6 & 7.3 & 8.3 & 8.3 & 7.6 & 7.8 & 8.7 & 9.2 & 9.0 & 9.2 & 8.3 & 9.3 \\
$60-64$ & 32.8 & 34.6 & 40.9 & 46.8 & 46.5 & 41.0 & 34.9 & 27.8 & 23.0 & 23.6 & 23.8 & 25.0 & 23.8 & 21.5 & 21.7 \\
$16-64$ & 7.6 & 7.6 & 8.2 & 9.0 & 9.6 & 9.2 & 9.2 & 9.2 & 9.0 & 9.3 & 9.2 & 9.4 & 9.7 & 10.2 & 11.1 \\
\hline
\end{tabular}

Source: Statistics Sweden, Labour Force Surveys. 
Table 10 shows the corresponding figures for women. There is also a decline in part-time work in the second half of the 1990s among women aged 60-64, but this decline is smaller than that for men and there is also a parallel decline among part-time work among women aged 55-59 and also among all women in the labour force.

Table 10. Per cent of women aged 55-64 with part-time work in 1990-2004

\begin{tabular}{llllllllllllllll}
\hline Age & 1990 & 1991 & 1992 & 1993 & 1994 & 1995 & 1996 & 1997 & 1998 & 1999 & 2000 & 2001 & 2002 & 2003 & 2004 \\
\hline $55-59$ & 50.2 & 49.2 & 48.0 & 48.7 & 48.6 & 47.6 & 46.6 & 45.8 & 44.4 & 36.2 & 34.9 & 33.7 & 32.4 & 30.7 & 31.8 \\
$60-64$ & 64.7 & 64.9 & 70.9 & 70.6 & 68.5 & 69.0 & 63.5 & 58.1 & 56.5 & 49.9 & 48.1 & 49.4 & 48.7 & 46.6 & 44.2 \\
$16-64$ & 45.2 & 45.4 & 45.5 & 46.3 & 46.3 & 45.9 & 44.7 & 44.3 & 43.5 & 35.9 & 34.8 & 34.1 & 34.0 & 33.9 & 34.4 \\
\hline
\end{tabular}

Source: Statistics Sweden, Labour Force Surveys.

The next step is to study the development of labour force participation among the same groups. See Table 11 for the development for men. The pattern is not very clear. Labour force participation increased among most, but not all one-year age groups in the second part of the 1990s. In the same period several important changes were made in the social insurance schemes and the economy recovered, especially in the last years of the decade. It is therefore difficult to say anything about the effects of the changes in the part-time system on labour force participation. In the early 2000s the labour force participation increased among those aged 60-64. The main factor behind this development is probably the new scheme for old age pensions with much stronger incentives for continued work than in the system it replaced. 
Table 11. Labour force participation among men aged 55-64 in 1990-2004 (per cent)

\begin{tabular}{llllllllllllllll}
\hline Age & 1990 & 1991 & 1992 & 1993 & 1994 & 1995 & 1996 & 1997 & 1998 & 1999 & 2000 & 2001 & 2002 & 2003 & 2004 \\
\hline $55-59$ & 87.4 & 86.2 & 85.4 & 82.8 & 82.0 & 82.2 & 83.1 & 82.3 & 83.6 & 84.2 & 83.9 & 83.1 & 83.9 & 83.0 & 83.8 \\
60 & 74.2 & 75.7 & 72.2 & 70.7 & 70.7 & 71.6 & 70.6 & 67.9 & 69.3 & 72.1 & 73.7 & 74.0 & 73.7 & 78.5 & 76.1 \\
61 & 70.9 & 70.9 & 67.7 & 61.4 & 62.4 & 64.9 & 68.0 & 63.7 & 60.3 & 63.1 & 66.5 & 68.2 & 67.3 & 69.9 & 72.5 \\
62 & 65.9 & 65.6 & 64.0 & 59.1 & 55.6 & 55.9 & 59.4 & 53.8 & 55.0 & 53.3 & 57.4 & 60.0 & 60.7 & 64.0 & 66.1 \\
63 & 58.0 & 59.8 & 53.4 & 53.1 & 48.3 & 51.3 & 52.4 & 49.9 & 45.1 & 48.0 & 43.6 & 51.0 & 51.2 & 55.1 & 58.9 \\
64 & 48.8 & 49.1 & 46.4 & 44.6 & 45.0 & 41.9 & 45.7 & 45.1 & 40.0 & 38.0 & 38.0 & 38.5 & 43.7 & 47.6 & 48.2 \\
$16-64$ & 87.0 & 86.0 & 84.0 & 80.9 & 79.4 & 80.2 & 80.0 & 79.1 & 79.0 & 79.5 & 80.2 & 80.5 & 79.8 & 79.9 & 79.7 \\
\hline
\end{tabular}

Source: Statistics Sweden, Labour Force Surveys.

Table 12 shows the corresponding figures for women. Labour force participation also increased among women in several of the age-year groups in the second half of the 1990s. But, again, it is not possible to draw any conclusions about the effects of the part-time pension system on labour force participation. As among men, labour force participation increased markedly among women aged 60-64 in the first half of the first decade of the $21^{\text {st }}$ century.

Table 12. Labour force participation among women aged 55-64 in 1990-2004 (per cent)

\begin{tabular}{llllllllllllllll}
\hline Age & 1990 & 1991 & 1992 & 1993 & 1994 & 1995 & 1996 & 1997 & 1998 & 1999 & 2000 & 2001 & 2002 & 2003 & 2004 \\
\hline $55-59$ & 78.8 & 79.3 & 78.8 & 77.2 & 77.6 & 77.3 & 78.5 & 78.3 & 78.4 & 78.9 & 79.1 & 79.4 & 79.1 & 79.2 & 79.4 \\
60 & 69.0 & 67.9 & 68.8 & 63.2 & 66.2 & 65.7 & 65.9 & 61.8 & 62.5 & 65.4 & 67.1 & 67.2 & 70.3 & 70.8 & 69.9 \\
61 & 62.2 & 63.9 & 62.0 & 58.3 & 53.1 & 59.5 & 58.6 & 56.9 & 53.7 & 59.8 & 58.7 & 62.0 & 63.1 & 66.5 & 67.0 \\
62 & 54.5 & 58.1 & 53.9 & 51.3 & 46.7 & 48.6 & 53.2 & 49.3 & 46.2 & 47.7 & 52.1 & 52.7 & 55.4 & 57.4 & 58.0 \\
63 & 46.7 & 43.9 & 44.9 & 38.0 & 39.1 & 37.7 & 39.6 & 41.6 & 31.7 & 30.9 & 35.1 & 37.1 & 42.5 & 45.8 & 49.3 \\
64 & 37.3 & 40.0 & 34.6 & 35.5 & 30.2 & 31.2 & 31.6 & 32.4 & 27.8 & 25.2 & 25.2 & 28.4 & 31.7 & 34.5 & 40.7 \\
$16-64$ & 82.6 & 81.7 & 79.9 & 77.2 & 75.7 & 76.1 & 75.6 & 74.5 & 73.9 & 74.8 & 75.5 & 76.2 & 76.1 & 76.2 & 75.7 \\
\hline
\end{tabular}

Source: Statistics Sweden, Labour Force Surveys. 
8. An estimation of the effects of the part-time pension system on the number of hours worked

It is difficult to estimate the effects of the part-time pension system on the number of hours worked. It is necessary to ascertain what the part-time pensioners would have done had they not had the part-time pension option, and we also need information on the number of hours worked before and after taking a part-time pension. I will attempt to make an estimation of the total effects but must underline that the calculations are based on data which is not perfect for the task. Figures have been used on the number of hours worked before and after receiving a part-time pension which the National Insurance Board has calculated in connection with an earlier study of the part-time pension scheme $^{19}$, and also estimations from Sundén (1994) on what the part-time pensioners would have done had they not had the option of a part-time pension.

First we will look at the number of hours worked before and after taking up a part-time pension. Values for the years 1991 and 1994 are shown in Table $13 .{ }^{20}$ The people worked on average slightly less than 40 hours a week before taking up a part-time pension women somewhat fewer hours than men. According to the data from the National Insurance Board, a not insignificant number of people were working more than 40 hours before taking a part-time pension, in some cases many hours more. As it is not clear how these high numbers of working hours should be interpreted, the calculation has been made using the figures received and by assuming that those with a work-week of more than 40 hours worked 40 hours. As seen in the table, the differences between the results given by the two methods are not large.

After taking a part-time pension people worked on average 24-25 hours - women somewhat more hours than men. Therefore, the reduction in working hours is less for women than for men (women work fewer hours before taking a part-time pension and more hours afterwards). The next step, also shown in the table, is to calculate the maximum share who could have continued to work as much as before if they had not taken a pension, without leading to a reduction in the total number of hours worked. We

\footnotetext{
${ }^{19}$ See Wadensjö (1996).

${ }^{20}$ I have also had access to the corresponding information from 1992 and 1993 but as the variations are small between the years I have chosen to only present the results for two of the four years.
} 
see that this share is slightly more than 60 per cent for men and around 65 per cent for women. (The share would have been 50 per cent if part-time pensioning on average had meant a change from full-time to half-time work, but that is not the case according to the information available). If the share who otherwise would have continued to work as much as before is higher than those percentages, the total number of hours worked will decline, if the shares are lower, the total number of hours will increase.

Table 13. Average number of working hours before and after being granted a part-time pension, and the share of the part-time pensioners who at most may have chosen parttime pension instead of continuing to work the same number of hours as before the pension if the total number of working hours should not decline

\begin{tabular}{|c|c|c|c|c|c|c|}
\hline & \multicolumn{3}{|c|}{1991} & \multicolumn{3}{|c|}{1994} \\
\hline & Men & Women & All & Men & Women & All \\
\hline $\begin{array}{l}\text { The average number of working hours before } \\
\text { getting a part-time pension }\end{array}$ & 39.95 & 37.82 & 39.09 & 39.88 & 37.89 & 39.08 \\
\hline $\begin{array}{l}\text { The number of working hours on average } \\
\text { before getting a part-time pension under the } \\
\text { assumption that those who have a reported } \\
\text { working week of more than } 40 \text { hours have a } \\
\text { work-week of } 40 \text { hours }\end{array}$ & 39.66 & 37.72 & 38.88 & 39.64 & 37.78 & 38.89 \\
\hline $\begin{array}{l}\text { The average number of working hours for } \\
\text { those with a part-time pension }\end{array}$ & 24.00 & 24.18 & 24.07 & 24.75 & 25.06 & 24.87 \\
\hline $\begin{array}{l}\text { The share of the part-time pensioners who at } \\
\text { most may have chosen a part-time pension } \\
\text { instead of continuing working the same } \\
\text { number of hours as before getting a pension } \\
\text { if the total number of working hours should } \\
\text { not decline (\%) }\end{array}$ & 60.1 & 63.9 & 61.6 & 62.1 & 66.1 & 63.6 \\
\hline $\begin{array}{l}\text { The same share calculated under the } \\
\text { assumption that those who have a reported } \\
\text { working week of more than } 40 \text { hours have a } \\
\text { work-week of } 40 \text { hours (\%) }\end{array}$ & 60.5 & 64.1 & 61.9 & 62.4 & 66.3 & 63.9 \\
\hline
\end{tabular}

It is possible to illustrate the method with an example. Assume that before taking up a part-time pension everyone works 39 hours a week and they all work 24 hours after pensioning. This means that the person who works part-time instead of "full-time" as a result of the offer of a part-time pension diminishes his labour supply by 15 hours (39 minus 24), and that the person who - without the option of a part-time pension - would have left the labour market, increases his labour supply by 24 hours (24 minus 0). In this 
example which is close to the information we have, the second effect is larger than the first one per person. It means that less than a 50 per cent change from leaving the labour force to working part-time is needed to get a net addition to the labour supply.

How large is the share who would have continued to work to the same extent in the absence of the part-time system? Sundén (1994) has analyzed the choice the individual would have made in the absence of the part-time pension system using data from the Level of Living Surveys (LNU) from 1974 and 1981 supplemented with register data. Her results indicate that the part-time pension system has reduced both the number of people who work full-time and the number who leave the labour market before reaching the ordinary retirement age (mainly by the disability pension system). The change from full-time work (until ordinary retirement age) to part-time work is the most frequent change for men (56.59 per cent of the men taking up part-time pension) but not for women (42.39 per cent of the women taking up a part-time pension). In both the cases the values are below the percentages calculated above. It indicates that the number of hours worked increases as a result of the part-time pension system. However, note that the calculations build on information from the different decades and the pattern may have changed from the 1980s to the 1990s. As Sundén stresses it would be very interesting to also use the later waves of the Level of Living Surveys (from 1991 and 2000).

The analysis is further developed in Table 14. We estimate the change in the average number of hours worked by using the information on the hours worked before and after being part-time pensioned, and the values from Sundén (1994) about the alternative employment status if the part-time pension system had not existed. Both the positive effect (working part-time instead of being full-time retired) and the negative one (a reduction of the working time) are in that way included. The table shows that the average number of working hours per part-time pensioned increases by $4-5$ hours. The number is considerably higher for women (8.2 - 9.0 hours) than for men (1.4 - 2.3 hours). The total effect also depends on the number of people who take up a part-time pension, and the number of part-time pensioners was considerably higher in 1994 than in 1991. The effect in 1991 was close to 6.7 million working hours and in 1994 almost 10.6 working hours. 
Table 14. Estimated effect on the numbers of hours worked per person with part-time pension given that 56.59 per cent of the male and 42.39 per cent of the female part-time pensioners would have continued to work the same number of hours (in most times fulltime work) before getting the pension and otherwise would not have worked

\begin{tabular}{|c|c|c|c|c|c|c|}
\hline & \multicolumn{3}{|c|}{1991} & \multicolumn{3}{|c|}{1994} \\
\hline & Men & Women & All & Men & Women & All \\
\hline $\begin{array}{l}\text { Estimated working hours effect per week per } \\
\text { part-time pensioner }\end{array}$ & 1.39 & 8.15 & 4.12 & 2.22 & 9.00 & 4.97 \\
\hline $\begin{array}{l}\text { Total effect in thousands of hours during the } \\
\text { year }\end{array}$ & 1310 & 5198 & 6507 & 2758 & 7646 & 10404 \\
\hline $\begin{array}{l}\text { Estimated working hours effect per week per } \\
\text { part-time pensioner under the assumption } \\
\text { that those who have a reported working week } \\
\text { of more than } 40 \text { hours have a work-week of } \\
40 \text { hours (\%) }\end{array}$ & 1.56 & 8.19 & 4.23 & 2.32 & 9.05 & 5.05 \\
\hline $\begin{array}{l}\text { Total effect in thousands of hours during the } \\
\text { year under the assumption that those who } \\
\text { have a reported working week of more than } \\
40 \text { hours have a work-week of } 40 \text { hours (\%) }\end{array}$ & 1472 & 5220 & 6691 & 2884 & 7686 & 10570 \\
\hline
\end{tabular}

Note. The number of work-weeks is assumed to be 45 in a year (52 weeks minus vacation and public holidays).

Source: Calculated by using information from Sundén (1994) regarding the shares who would have continued to work to the same extent if not getting a part-time pension and from Table 13 regarding the number of hours worked before and after getting a part-time pension.

To conclude: the effect of the part-time pension system is an increase in the number of hours worked in the economy, especially among women. It should be underlined that it is important to continue studies in the field by using databases that contain more individuals and cover a longer time period.

\section{Summary and conclusion}

Sweden had a subsidized social security part-time pension system from 1976 up to the turn of the century. It was a part of the social security system and was financed by a payroll fee. A take up of a part-time pension did not influence the old age pension (from the age of 65). There were additions to the part-time pensions from the social security parttime pension system in three of the four main collective bargaining areas (state employees, for those employed by the counties and municipalities, and for white-collar workers in the private sector). 
From the start of the new scheme the part-time pension was an option for employees who were 60 years or older (up to the age of 65). The minimum reduction of working hours was 5 hours, the minimum remaining working hours 17 and the replacement rate 65 per cent of the earnings lost due to the reduction hours. With a progressive income tax system the actual replacement rate was in fact higher. To be able to get a part-time pension the employer had to give his consent. The system became very popular in a short time. Many people applied and the employers were generally positive. The employers saw it as a possibility to restructure and rejuvenate the work force without being forced to pay a severance pay or to go through complicated negotiations with the unions.

The part-time pension was a sensitive political issue leading to a row of conflicts. The Social Democratic Party, who introduced it, was in favour of it and the Liberal and Conservative parties were against it. The system changed in 1981 after a proposal to the Parliament by the then Liberal-Conservative government. The replacement rate was lowered to 50 per cent. The number of new pensions declined substantially. A Social Democratic government took office after the election in 1982 and after some years, in 1987, the replacement rate was enhanced back to 65 per cent. The number of new pensions increased again. A lesson from these election outcome-initiated changes in the part-time pension system is that the replacement rate is very important for the share of those entitled who are applying.

After the election of 1991 a new Liberal-Conservative government was formed. It tried both to lower the replacement rate and to abolish the system totally. The government's proposal in both cases lost in Parliament due to that a small right-wing party which had some seats in the parliament in the period 1991-1994 and in almost all issues supported the Liberal-Conservative government in this case supported the Social Democratic opposition.

The part-time pension did however change in the 1990s. As a part of the reform of the old age pension system and as part of a compromise between the Liberal-Conservative government and the Social Democratic opposition, the part-time pension plan came to an end in two steps. The formal motivation was that a subsidized part-time pension was not 
in accordance with the general principles of the new old age pension system - that the pensions should be based on life-time earnings.

As mentioned, the dismantling of the part-time pension took part in two steps. In 1994 the scheme was made less favourable in several respects. The maximum reduction of hours was set to 10, the replacement rate was lowered to 55 per cent, and the lowest eligible age was increased from 60 to 61 . The number of applications became very low. For the first year it could be explained by that in that year no new people became eligible due to the increase in lowest retirement age by one year and that most who took a parttime pension started to do so upon reaching the age of 60. But the number of people applying for a part-time pension continued to be few. Then in the second step (already decided on in 1994) no new part-time pensions were granted from January 1, 2001. A part-time pension system may induce some people to work part-time instead of fulltime and others to work part-time instead of leaving the labour market. The effect in hours worked in the economy also depends on the number of hours worked before starting to work part-time (or leave the labour market) and the numbers of hours worked when taking a part-time pension. The study shows that the total effect is an increase in the number of hours worked and that this effect is larger for women than for men. There may be other effects: the financing of the system (payroll fees) may have effects on labour supply, and the take-up of a part-time pension (instead of working full-time) may influence the health status and by that the incidence of future take-ups of a disability pension.

To summarize, there are some findings from the large-scale and long Swedish experiment with a part-time pension scheme.

1. The number of people who apply varies considerably with the replacement rate but is also sensitive to other rules, for example rules regarding how many hours of working-time reduction it is possible to get compensation for.

2. There are effects going in different directions: some people make a choice of working part-time instead of full-time and some people work part-time instead of leaving the labour market. 
3. The estimated effect is that the part-time pension system increased the number of hours worked.

A part-time pension system has now been re-introduced for one important group in the labour market - the state employees. It is closely modelled after the former part-time pension system. Some private employers have also introduced part-time pension systems of their own. It should also be added that there is a part-time pension option in the new old age pension system as well as in the former old age pension system. But part-time pensions according to this option are not subsidized, and lead to an actuarially reduced old age pension. There also exist part-time pensions in the disability pension system. The number of partial pensions has tended to increase in those two systems.

\section{References}

Allen, Steven G. (2004), “The Value of Phased Retirement”, NBER Working Paper 10531.

Allen, Steven G., Clark, Robert L. and Ghent, Linda S., (2003), "Phasing into Retirement”, Industrial and Labor Relations Review, Vol. 58, no. 1, 112-127.

Chen, Yung-Ping (2004), “Report on Phased Retirement for the AARP”, June 30.

Chen, Yung-Ping and Scott, John C. (2003), “Gradual Retirement: An Additional Option in Work and Retirement”, North American Actuarial Journal, Vol. 7, no. 3, 62-74.

Clark, Denise M. (2002), “The Role of Multiemployer Defined Benefit Plans in an Era of Phased Retirement”, Retirement Implications of Demographic and Family Change Symposium, San Francisco, June 2002.

Delsen, Lei and Reday-Mulvey, Geneviève (eds.) (1996), Gradual Retirement in the OECD Countries, Aldershot: Dartmouth.

Even, William E. and Macpherson, David A. (2004), “Do Pensions Impede Phased Retirement?”, IZA DP no. 1353.

Ginsburgh, Helen (1985), "Flexible and partial retirement for Norwegian and Swedish workers”, Monthly Labor Review, Vol. 108, no. 10, 33-43.

Gustman, Alan L. and Steinmeier, Thomas L. (1981), "Partial Retirement and the Analysis of Retirement Behavior”, NBER Working Paper 763.

Herbertsson, Tryggvi Thor (2001), Why Icelanders Do Not Retire Early, Stockholm: Pensionsforum.

Landelius, Per Svante (2003), "Kollektivavtalade tjänstepensioner som incitament för högre arbetskraftsdeltagande”, Promemoria, Senior 2005, Äldrepolitik för framtiden. 
Latulippe, Denis and Turner, John (2000), “Partial Retirement and Pension Policy in Industrialized Countries”, International Labour Review, Vol. 138, no. 2, 179-195.

O’Reilly, Denis and Fagan, Collette (eds.) (1998), Part-Time Prospects, London: Routledge.

Penner, Rudolph G., Perun, Pamela and Steuerle, Eugene (2002), “Legal and Institutional Impediments to Partial Retirement and Part-time Work by Older Workers”, Washington: The Urban Institute.

Pierson, Paul (2000), “Increasing Returns, Path Dependence, and the Study of Politics”, American Political Science Review, Vol. 94, no. 2, 251-267.

Purcell, Patrick J. (2000), “Older workers: employment and retirement trends”, Monthly Labor Review, October, 19-30.

Rasmussen, Erling, Lind, Jens and Visser, Jelle (2004), "Divergence in Part-Time Work in New Zealand, the Netherlands, and Denmark", British Journal of Industrial Relations, Vol. 42, no. 4, 637-658.

Riksförsäkringsverket (1994), Delpensioneringen t o m 1993. Statistikinformation 1994:2.

Riksförsäkringsverket (1995), Delpensioneringen t o m 1994. Statistikinformation 1995:1.

Riksförsäkringsverket, (1997), Delpensioneringen t o m 1996, Statistikinformation Is-I, 1997:2.

Riksförsäkringsverket (2001), RFV Redovisar 2001:3, “Delpensionärerna - vilka är de?”

Ryan, Paul, Garonna, Paolo and Edwards, Richard (eds.) (1991), The Problem of Youth:

the Regulation of Youth Employment and Training in Advanced Economies, London:

Macmillan.

Scahill, Patricia L. and Forman, Jonathan Barry (2002), "Protecting Participants and Beneficiaries in a Phased Retirement World”, Retirement Implications of Demographic and Family Change Symposium, San Francisco, June 2002.

SFS 1979:84, Lag om delpensionförsäkring.

SFS 1987:364, 1990:671, 1992:1743, Lag om ändring av lagen om delpensionförsäkring.

Statistics Sweden, ’Labour Force Surveys (various issues).

Statistics Sweden (2004), ”The Work Environment 2003”, Statistiska Meddelanden Am 68 SM0401.

Swedenborg, Birgitta (ed.) (2003), Varför är svenskarna så sjuka?, Stockholm: SNS Förlag.

Turner, John (2003), “Raising the Pensionable Age in Social Security”, Public Policy Institute \& AARP, January.

Sundén, Annika (1994), Early Retirement in the Swedish Pension System, doktorsavhandling, Ithaca: Cornell University.

Wadensjö, Eskil (1991), “Partial Exit: Sweden”, in Martin Kohli, Martin Rein, Anne Marie Guillemard and Hermann van Gunsteren, (eds.), Time for Retirement: 
Comparative studies of early exit from the labor force, Cambridge: Cambridge University Press.

Wadensjö, Eskil (1993). "Partial Exit Options in Sweden: Recent and Future Changes”, Generations, Vol. 17, no. 4, 15-19.

Wadensjö, Eskil (1996), “Gradual Retirement in Sweden” in Lei Delsen and Geneviève Reday-Mulvey (eds.), Gradual Retirement in the OECD Countries, Aldershot: Dartmouth.

Wadensjö, Eskil and Sjögren, Gabriella (2000), Arbetslinjen för äldre i praktiken. En rapport för Riksdagens Revisorer, Stockholm: Institutet för social forskning.

Weaver, R. Kent (2003), “The Politics of Public Pension Reform”, Center for Retirement Research at Boston College.

Wise, Lois (1990), "Partial and Flexible Retirement: The Swedish System”, The Gerontologist, Vol. 30, no. 3, 355-361.

Visser, Jelle (2002), “The first part-time economy in the world: a model to be followed?", Journal of European Social Policy, Vol. 12, no. 1, 23-42.

Wong, Aliya (2002), "Defined Benefit Plans in an Era of Phased Retirement", "Protecting Participants and Beneficiaries in a Phased Retirement World", Retirement Implications of Demographic and Family Change Symposium, San Francisco, June 2002. 